\title{
PHYTOCHEMICAL ANALYSIS, ASSESSMENT OF ANTIPROLIFERATIVE AND FREE RADICAL SCAVENGING ACTIVITY OF MORUS ALBA AND MORUS RUBRA FRUITS
}

\author{
FAROUK K EL-BAZ ${ }^{1}$, AMAL Z HASSAN ${ }^{2}$, HOWAIDA I ABD-ALLA ${ }^{2 *}$, HANAN F ALY ${ }^{3}$, KHALED MAHMOUD ${ }^{4}$
}

${ }^{1}$ Department of Plant Biochemistry, Division of Agriculture and Biology Research, National Research Centre, Dokki-Giza 12622, Egypt. ${ }^{2}$ Department of Chemistry of Natural Compounds, Division of Pharmaceutical Industries Research, National Research Centre, Dokki-Giza 12622, Egypt. ${ }^{3}$ Department of Therapeutic Chemistry, Division of Pharmaceutical Industries, National Research Centre, Dokki-Giza 12622, Egypt. ${ }^{4}$ Department of Pharmacognosy, Division of Pharmaceutical Industries, National Research Centre, Dokki-Giza 12622, Egypt. Email: howaida_nrc@yahoo.com

Received: 20 February 2017, Revised and Accepted: 15 March 2017

ABSTRACT

Objective: Mulberry is a nontoxic commonly eaten plant, belongs to the Morus and used in folk medicine in the remedy of dysentery, antiphlogistic, diuretic, expectorant, and antidiabetic. The purpose of this study is to evaluate the antiproliferative and radical scavenging activity of the total alcoholic and successive fractions thereof of Morus alba and Morus rubra fruits. In addition, the chemical composition of the bioactive fractions of each species was investigated.

Methods: The antiproliferative potential of 8 extracts on 4 human cancer cell lines, hepatocellular carcinoma (HepG2), Caucasian breast adenocarcinoma (MCF7), prostate (PC3), and colon carcinoma (HCT116) in addition to one normal cell line namely human normal immortalized skin fibroblast cells (BJ1) were carried out. Cell viability was determined using MTT assay. The potency was compared with the reference drug doxorubicin. These extracts were also assayed for 1,1-diphenyl-2-hydrazyl free radical scavenging activities. After saponification of the n-hexane fraction, unsaponifiable matter and fatty acid methyl esters were analyzed by gas liquid chromatography (GLC). The chemical composition of the bioactive fractions was investigated using gas chromatography/mass spectrometry (GC/MS) analysis.

Results: All the extracts showed significant free radical scavenging activity dose-dependently. The $n$-hexane and dichloromethane (DCM) fractions of M. rubra exhibited potent cytotoxic activity on almost cancer cell lines. In the same pattern, ethyl acetate (EtOAc) of M. rubra has moderate cytotoxic activity against all cell lines except HepG2. DCM fraction of M. alba possessed both radical scavenging and high potential antiproliferated activities against HCT116 and MCF7 with inhibitory concentration of 43.9 and $32.3 \mu \mathrm{g} / \mathrm{ml}$, respectively, while it showed no cytotoxic effect on BJ1. GLC analysis showed the major hydrocarbons in M. alba and M. rubra were heptacosane and docosane, respectively. Sterols were similar in both species but with different ratios and cholesterol was the major one. Palmitic and margaric were the major saturated fatty acid while arachidonic was the major unsaturated fatty acid in both species. GC/MS analysis showed the main compound in DCM fraction of each Morus species was palmitic acid. Furthermore, 1,11-bis-(methoxycarbonyl-ethenyl)-10,2-dihydroxy-cycloeicosane and linolelaidic acid, methyl ester were the main compounds in the EtOAc fraction of each Morus species. Whereas, the main compounds in alcoholic extract of M. alba and M. rubra were methyl-14-methylpentadecanoate and 1,2-0-isopropylyidene-4-nonene-1,2,3-triol, respectively.

Conclusions: The results observed remarkable biological activity of the successive fractions of $M$. rubra more than those of M. alba and confirmed its importance as a natural bioactive source. Morus species are good candidates to be promising as possible sources for future antitumor and antioxidants in food and pharmaceutical formulations. The strong activity partly explains the potential effects of Morus species for the treatment of cancer and degenerative diseases caused by free radicals.

Keywords: Morus alba, Morus rubra, Radical scavenging, Antiproliferated activity, BJ1, Gas liquid chromatography, Gas chromatography/mass spectrometry.

(c) 2017 The Authors. Published by Innovare Academic Sciences Pvt Ltd. This is an open access article under the CC BY license (http://creativecommons. org/licenses/by/4. 0/) DOI: http://dx.doi.org/10.22159/ajpcr.2017.v10i6.18029

\section{INTRODUCTION}

Cancer is the leading cause of mortality worldwide and its incidence is still increasing especially due to diet, environment and carcinogenic virus infections [1]. Extensive damage to DNA, protein, and lipid could be related to the free radicals react with biomolecules, which are considered to be contributed to degenerative diseases of aging and cancer. Cancer, one major cause of death, is salient "free radical" disease. Antioxidant therapy is vital in scavenging free radicals and plays an important role in the later stages of cancer development $[2,3]$. Consumption of dietary and plant-derived antioxidant appears to be a suitable alternative preventing the formation of free radicals [4].

Resistance to several anticancer drugs has stimulated efforts to search for natural effective, nontoxic agents without adverse effects [5,6]. Many natural products have studied to find the new potent source of bioactive antitumor molecules $[3,7]$. The worldwide use of medicinal plants has become more and more important in primary health care especially in developing countries. Different extracts of natural products were found to possess antiproliferative effects in cancer. Moraceae plants showed a wide range of bioactive features including anti-inflammatory, antioxidative, and many useful antitumor agents developed from this family [7,8]. Mulberry is a fast-growing deciduous, nutritious, palatable, and nontoxic plant belongs to the Morus, a plant genus of the family Moraceae. The fruits may be eaten raw or cooked, and the herb has been used as a remedy for dysentery, antiphlogistic, anthelmintic, diuretic, expectorant, and antidiabetic in traditional medicine $[2,8]$. Few species of mulberry were evaluated for their edible fruits and reports indicate that mulberry fruits are a good source of micronutrients, stilbenes, polyhydroxylated alkaloids, flavonoids, and benzofurans [5,9]. These compounds have shown a wide range of bioactive features including hypoglycemic, neuroprotective functions, anti-inflammatory, and antioxidative effects [9-11]. 
The objective of the current exposition was to investigate the antiproliferative and radical scavenging effect of two Morus species involving purple mulberry (Morus rubra) and white mulberry (Morus alba). This work describes theidentification of phytoconstituents of the total ethanol extract, dichloromethane (DCM) and ethyl acetate (EtOAc) fractions using gas chromatography/mass spectrometry (GC/MS) analysis for the first time along with the hydrocarbons, sterols and fatty acids of the $n$-hexane fraction $(\mathrm{Hx})$ by gas liquid chromatography (GLC) analysis.

\section{METHODS}

\section{Collection of plant material}

Fresh fruits of white M. alba and purple M. rubra were collected in the Delta region, Egypt. The berries were selected according to uniformity of shape and color. The identification of the plant was confirmed by Therese Labib, Herbarium Section, El-Orman Botanical Garden, Giza, Egypt. The fresh fruit samples were cleaned, stored in polyethylene bags and frozen at $-20^{\circ} \mathrm{C}$, till further use.

\section{Preparation of extracts for bioassays}

The fresh fruits of each species (200 g) were extracted separately with $700 \mathrm{ml}$ of $70 \%$ aqueous ethanol (EtOH) for $3 \mathrm{hrs}$, on an orbital shaker in the dark at room temperature. Each extract was separated by centrifugation $(13,000 \times \mathrm{g}, 10$ minutes), the supernatant was taken, the residue was re-suspended in $50 \mathrm{ml}$ of the same solvent, and the mixture was again separated by centrifugation. The two resulting supernatants were then combined and concentrated under reduced pressure at $40^{\circ} \mathrm{C}$ till dryness to get $2.63 \%$ and $2.50 \%$ of crude EtOH extract of M. alba and M. rubra, respectively. The residue was suspended in the least amount of water and transferred to a separator funnel, then successively fractionated with solvents of increasing polarity, $\mathrm{Hx}$, DCM and EtOAc. Their residues were stored in the dark at $-20^{\circ} \mathrm{C}$. For antitumor bioassay, the residue of each extract was re-dissolved in $1 \mathrm{ml}$ of dimethyl sulfoxide at a concentration of $100 \mathrm{mg} / \mathrm{ml}$ and diluted with tissue culture medium before use.

\section{Cell viability assay}

Cell viability for four cancer cell lines, namely, human hepatocellular carcinoma (HepG2), MCF7, HCT116 and PC3 beside one normal cell line $\mathrm{BJ}-1$, was assessed by the mitochondrial-dependent reduction of the yellow MTT assay to purple formazan [12]. All the following procedures were done in a sterile area using a laminar flow cabinet biosafety Class II level (Baker, SG403INT, Sanford, ME, USA). Cells were suspended in Roswell Park Memorial Institute 1640 medium for HepG2, MCF7, PC3, and HCT116. BJ-1 was maintained in Dulbecco's modified Eagle Medium (DMEM)-F12. All media was supplemented with $1 \%$ antibiotic-antimycotic mixture $(10,000 \mu \mathrm{g} / \mathrm{ml}$ potassium penicillin, $10,000 \mu \mathrm{g} / \mathrm{ml}$ streptomycin sulphate and $25 \mu \mathrm{g} / \mathrm{ml}$ amphotericin B) and $1 \% \mathrm{~L}$-glutamine at $37^{\circ} \mathrm{C}$ under $5 \% \mathrm{CO}_{2}$. Cells were batch cultured for 10 days and then seeded at a concentration of $10 \times 10^{3}$ cells per well in fresh complete growth medium in 96-well microtiter plastic plates at $37^{\circ} \mathrm{C}$ for $24 \mathrm{hrs}$ under $5 \% \mathrm{CO}_{2}$ using a water-jacketed carbon dioxide incubator (Sheldon, TC2323, Cornelius, OR, USA). The media were aspirated, fresh medium (without serum) was added, and cells were incubated either alone (negative control) or with different concentrations $(100,50,25,12.5,6.25,3.125,1.56$, and $0.78 \mu \mathrm{g} / \mathrm{ml})$ to calculate the inhibitory concentration $\left(\mathrm{IC}_{50}\right.$ ) and $\mathrm{IC}_{90}$ of the promising extract/fraction. After $48 \mathrm{hrs}$ of incubation, the medium was aspirated, $40 \mu \mathrm{l}$ MTT salt $(2.5 \mu \mathrm{g} / \mathrm{ml})$ was added to each well and incubated for further $4 \mathrm{hrs}$ at $37^{\circ} \mathrm{C}$ under $5 \% \mathrm{CO}_{2}$. To stop the reaction and to dissolve the formed crystals, $200 \mu \mathrm{l}$ of $10 \%$ sodium dodecyl sulfate in deionized water was added to each well and incubated overnight at $37^{\circ} \mathrm{C}$ [13]. Doxorubicin was served as positive control. The absorbance was then measured using a microplate multi-well reader (Bio-Rad Laboratories Inc., model 3350, Hercules, California, USA) at $595 \mathrm{~nm}$ and a reference wavelength of $620 \mathrm{~nm}$. The percentage of change in viability was calculated according to the formula: ([Reading of extract/reading of negative control] -1$) \times 100$. All cell lines were generously provided by Professor Stig Linder, Oncology and Pathology Department, Karolinska
Institute, Stockholm, Sweden. A probit analysis was performed for IC $_{50}$ and $\mathrm{IC}_{90}$ determination using SPSS 11 program.

\section{2,2-diphenyl-1-picrylhydrazyl (DPPH) free radical scavenging assay}

The ability of different extracts to scavenge DPPH free radical were determined according to Goveas and Abraham method [14]. DPPH and ascorbic acid were purchased from Sigma Chemical Co. (St. Louis, MO, USA). Ethanolic solution of DPPH $(0.1 \mathrm{mM})$ was prepared, to give the initial absorbance value of 0.993 at $517 \mathrm{~nm}$. The different concentration of samples in $0.1 \mathrm{ml}$ of each sample (with appropriate dilution if necessary) was added to $3.0 \mathrm{ml}$ of ethanolic DPPH solution. After incubation for 30 minutes in the dark, the absorbance was measured at $517 \mathrm{~nm}$ using ultraviolet/visible spectrophotometer (Lambda 25, PerkinElmer, USA). Ascorbic acid was used as standard. Control was prepared by mixing $2 \mathrm{ml}$ of $0.1 \mathrm{mM}$ DPPH solution with $1 \mathrm{ml}$ of methanol. Statistical analysis is carried out using SPSS computer program (version 8), where unshared letters are significant at $P<0.05$. Lower absorbance values of reaction mixture indicate higher free radical scavenging activity. The percentage of scavenging was calculated using the following formula:

Scavenging $\%=\left[1-\left(\mathrm{A}_{\text {sample }}-\mathrm{A}_{\text {blank }} / \mathrm{A}_{\text {control }}\right)\right] \times 100 \%$.

\section{Chemical characterization}

Preparation of the lipoidal matter

Each fresh sample $(10 \mathrm{~g})$ was exhaustively extracted with $\mathrm{Hx}$ for $6 \mathrm{hrs}$ using Soxhlet extractor apparatus (Sigma-Aldrich).

\section{Investigation of the lipoidal matter}

Determination of phytosterol and hydrocarbon contents

Each $\mathrm{Hx}$ was separately saponified [15] by refluxing with $50 \mathrm{ml}$ alcoholic potassium hydroxide (10\%) in a water bath for 2 hrs. After cooling, $50 \mathrm{ml}$ of water was added, and the solution was extracted with chloroform. The organic phase was washed with water until it became alkali free and was then dried over anhydrous sodium sulfate. The solvent was evaporated to afford the unsaponifiable matters and the fatty acids.

\section{Preparation of fatty acid methyl esters}

The isolated free fatty acids were subjected to methylation by refluxing with absolute methanol and sulphuric acid for 2 hrs, extracted with ether, evaporated and analyzed by GLC [16].

\section{Gas liquid chromatographic (GLC) analysis}

Both the unsaponifiable and the saponifiable fractions of each Morus species were studied to identify their contents using GLC analysis. GLC conditions of the unsaponifiable matter and fatty acids were performed on Agilent Technologies (6890N)-Network-GC system equipped by a flame ionization detector. Nitrogen gas was used as a carrier gas. The analysis of the unsaponifiable matter was performed using capillary column (HP-5 phenyl methyl siloxane) and oven temperature at $80^{\circ} \mathrm{C} / 8$ minutes from 80 to $350^{\circ} \mathrm{C}$. The operating conditions for fatty acid methyl ester analysis were capillary column HP-5\% 5-phenyl methyl siloxane $(30 \mathrm{~m} \times 320 \mathrm{um} \times 0.25 \mathrm{um})$; column maximum temperature was $325^{\circ} \mathrm{C}$. Detector and injection temperature was $250^{\circ} \mathrm{C}$. Oven temperature was from 50 to $350^{\circ} \mathrm{C}$ with a rate $50^{\circ} \mathrm{C} / 10$ minutes.

\section{GC/MS analysis}

GC/MS analysis was performed using a Thermo Scientific, Trace GC ultra/ISQ Single Quadrupole MS, TG-5MS fused silica capillary column ( $30 \mathrm{~m}, 0.251 \mathrm{~mm}, 0.1 \mathrm{~mm}$ film thickness). An electron ionization system with ionization energy of $70 \mathrm{eV}$ was used. Carrier gas was helium at a constant flow rate of $1 \mathrm{ml} /$ minute. The injector and MS transfer line temperature was $280^{\circ} \mathrm{C}$. The initial temperature oven was programed at $40^{\circ} \mathrm{C}$ (hold 3 minutes) to $280^{\circ} \mathrm{C}$ as a final temperature at an increasing rate of $5^{\circ} \mathrm{C} /$ minutes (hold 5 minutes). The constituents were identified by comparison of their mass spectral fragmentation patterns with 
those of the available database libraries, Wiley (Wiley International, Colorado, USA) and National Institute of Standards and Technology, Colorado, USA, and/or published data [17].

\section{RESULTS}

\section{Antiproliferative and safety to normal cells activities}

In vitro cytotoxicity test was carried out using four human cancer cell lines and one normal cell line were used to assess the antiproliferation activity of eight fractions of the two Morus species. The data in Table 1 showed that 5 extracts with high cytotoxic activity $(\geq 75 \%)$ against at least one cancer cell line. The results indicated that DCM of M. alba has potent activity against HCT116 and MCF7 with $\mathrm{IC}_{50} 32.3 \mu \mathrm{g} / \mathrm{ml}$ and $43.9 \mu \mathrm{g} / \mathrm{ml}$, respectively. EtOAc fraction of $M$. alba with $\mathrm{IC}_{50} 56.5 \mu \mathrm{g} / \mathrm{ml}$ for HCT116 and IC $54.6 \mu \mathrm{g} / \mathrm{ml}$ for MCF7. The best results were found for DCM fraction of M. alba that has not any activity against BJ1 (normal cell line) at $100 \mu \mathrm{g} / \mathrm{ml}$, while EtOAc fraction of $M$. alba has moderate activity on the same cell line (50\% at $100 \mu \mathrm{g} / \mathrm{ml})$. DCM fraction of $M$. alba has the same effect of doxorubicin on HCT116 but more safe where has not any effect on normal cell line.

\section{DPPH scavenging activity}

From the Table 2, DPPH scavenging activity it can be declared that EtOH exhibited potent antioxidant activity that increased with increasing amount of extract concentration, which was compared with standard ascorbic acid at different concentrations. The EtOAc, DCM and finally $\mathrm{Hx}$ of purple berry showed appropriate activities followed by the white berry in a dose-dependent manner (dose-dependent relationship).

\section{Chemical characterization and phytochemical analysis Extraction yield}

The results showed that the extraction yields obtained was affected by the solvent used. Table 3 shows the extraction percent yields $(\mathrm{w} / \mathrm{w})$ which obtained in the following descending order; EtOH $>$ EtOAc $>$ DCM $>\mathrm{Hx}$ in each Morus species extracts.

\section{GLC of lipoidal matter of $M$. alba and $M$. rubra}

The Hx fraction was concentrated in vacuo to yield 130.5 and $110.0 \mathrm{mg}$ of oily dry residue, representing $1.30 \%$ and $1.10 \%$ of the fresh fruit of M. alba and M. rubra, respectively. Percentages of the unsaponifiable matter were found to be $0.80 \%$ and $0.56 \%$, while the total fatty acids were $27.3 \%$ and $23.5 \%$ of $M$. alba and M. rubra, respectively.

GLC analysis of the unsaponifiable fractions of white M. alba and purple M. rubra revealed the presence of 21 and 20 compounds in Hx fraction, respectively (Table 4). Hydrocarbon compounds were the major content $(71.93 \%$ and $66.96 \%$, respectively) in which heptacosane $(13.46 \%)$ was the major one followed by the presence of octacosane (8.94\%) in M. alba unsaponifiable fraction, whereas docosane (10.58\%) was the major hydrocarbon followed by tricosane (7.67\%) in M. rubra unsaponifiable fraction. Hx fraction of M. alba showed the presence of pentadecane which did not present in M. rubra.

Four sterols (Fig. 1) were found in both M. alba and M. rubra $(28.07 \%$ and $33.04 \%$, respectively). Sterols were similar in both species unsaponifiable fractions but with different ratios. Cholesterol was the major one in both $(14.54 \%$ and $11.96 \%)$ whereas $\beta$-sitosterol $(2.45 \%$ and $7.23 \%)$ and campesterol (5.91\% and 6.76\%) were present in appropriate amount in both M. alba and M. rubra unsaponifiable fraction, respectively. Furthermore, stigmasterol was present with ratios $5.17 \%$ and $7.09 \%$, respectively.

GLC analysis of fatty acid methyl esters fraction revealed the presence of 16 and 17 compounds; representing $99.50 \%$ and $99.0 \%$ of the total identified compounds M. alba and M. rubra, respectively (Table 5). 9 and 10 saturated fatty acids represented $50.81 \%$ and $47.84 \%$ of the total fatty acids content, while 7 of mono-, di-, tri-, and tetra-unsaturated fatty acids represented $48.69 \%$ and $51.16 \%$ of M. alba and M. rubra, respectively. Palmitic acid (19.54\%) was the major saturated fatty acids

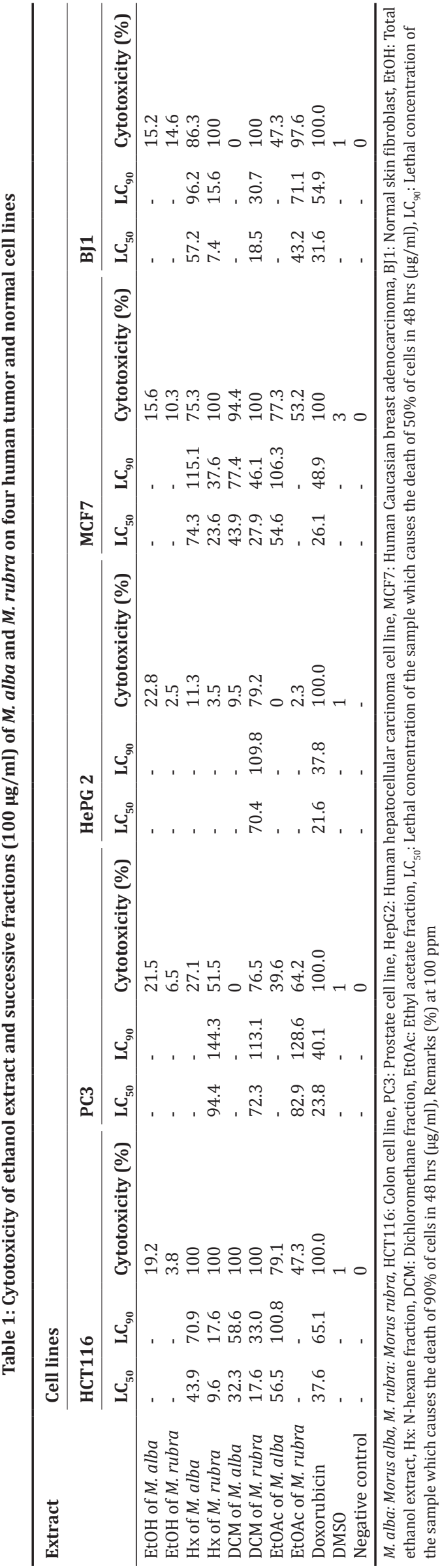


Table 2: DPPH scavenging activity assay of $M$. alba and $M$. rubra

\begin{tabular}{|c|c|c|c|c|}
\hline \multirow[t]{2}{*}{ Extract/fraction } & \multirow[t]{2}{*}{ Morus species } & \multirow[t]{2}{*}{ Concentrations ( $\mu \mathrm{g})$} & \multicolumn{2}{|c|}{ Scavenging percentage } \\
\hline & & & Ascorbic acid & DPPH \\
\hline \multirow[t]{5}{*}{$\mathrm{EtOH}$} & M. alba & 50 & $68.80 \pm 0.87^{i}$ & $33.90 \pm 1.17^{\text {ef }}$ \\
\hline & & 150 & $85.13 \pm 4.54^{\mathrm{ef}}$ & $66.6 \pm 4.34^{\mathrm{d}}$ \\
\hline & M. rubra & 50 & $75.22 \pm 4.00^{\mathrm{cd}}$ & $34.13 \pm 2.16^{\mathrm{ef}}$ \\
\hline & & 100 & $78.17 \pm 0.46^{\mathrm{bc}}$ & $54.34 \pm 3.47^{\mathrm{gh}}$ \\
\hline & & 150 & $80.03 \pm 4.56^{\mathrm{b}}$ & $69.88 \pm 3.11^{c}$ \\
\hline \multirow[t]{6}{*}{ EtOAc } & M. alba & 50 & $73.56 \pm 3.10^{\mathrm{de}}$ & $30.01 \pm 2.07^{\mathrm{ef}}$ \\
\hline & & 100 & $76.45 \pm 0.12^{\mathrm{cd}}$ & $30.48 \pm 1.22^{\text {ef }}$ \\
\hline & & 150 & $80.44 \pm 2.16^{\mathrm{b}}$ & $37.30 \pm 3.18^{j}$ \\
\hline & M. rubra & 50 & $69.80 \pm 1.26^{\mathrm{fg}}$ & $32.00 \pm 2.37^{\mathrm{ef}}$ \\
\hline & & 100 & $72.44 \pm 2.05^{\mathrm{efg}}$ & $34.06 \pm 1.23^{j}$ \\
\hline & & 150 & $83.49 \pm 3.81^{\mathrm{dg}}$ & $46.43 \pm 1.85^{\mathrm{k}}$ \\
\hline \multirow[t]{5}{*}{ DCM } & M. alba & 50 & $75.34 \pm 2.29^{\mathrm{fg}}$ & $25.10 \pm 0.37^{1}$ \\
\hline & & 100 & $82.98 \pm 3.05^{\mathrm{dg}}$ & $31.22 \pm 0.87^{\mathrm{ef}}$ \\
\hline & & 150 & $87.49 \pm 3.81^{\mathrm{ef}}$ & $40.11 \pm 2.22^{\mathrm{cd}}$ \\
\hline & & 100 & $80.18 \pm 3.35^{\mathrm{dg}}$ & $33.23 \pm 2.12^{\mathrm{ef}}$ \\
\hline & & 150 & $83.56 \pm 2.71^{\mathrm{dg}}$ & $45.00 \pm 1.85^{\mathrm{k}}$ \\
\hline \multirow[t]{6}{*}{$\mathrm{Hx}$} & M. alba & 50 & $77.76 \pm 2.16^{\mathrm{fg}}$ & $20.00 \pm 1.00^{\mathrm{m}}$ \\
\hline & & 100 & $82.18 \pm 4.56^{\mathrm{dg}}$ & $31.46 \pm 1.21^{\mathrm{ef}}$ \\
\hline & & 150 & $87.22 \pm 3.34^{\mathrm{ef}}$ & $35.43 \pm 1.85^{j}$ \\
\hline & M. rubra & 50 & $74.11 \pm 2.66^{\mathrm{fg}}$ & $22.11 \pm 1.52^{\mathrm{m}}$ \\
\hline & & 100 & $82.00 \pm 3.05^{\mathrm{dg}}$ & $33.46 \pm 0.87^{\mathrm{ef}}$ \\
\hline & & 150 & $87.49 \pm 4.00^{\mathrm{ef}}$ & $38.43 \pm 1.85^{\mathrm{cd}}$ \\
\hline
\end{tabular}

M. alba: Morus alba, M. rubra: Morus rubra, EtOH: Total ethanol extract, Hx: N-hexane fraction, DCM: Dichloromethane fraction, EtOAc: Ethyl acetate fraction. Unshared letters between groups (b-m) are the significance values at $P<0.05$

Table 3: Percent yields (w/w) of extract/fractions of $M$. alba and M. rubra

\begin{tabular}{lll}
\hline Solvent & $\mathbf{\%}$ & \\
\cline { 2 - 3 } & M. alba & M. rubra \\
\hline EtOH & 2.63 & 2.50 \\
Hx & 0.31 & 0.20 \\
DCM & 0.63 & 0.43 \\
EtOAc & 0.82 & 0.61 \\
\hline
\end{tabular}

M. alba: Morus alba, M. rubra: Morus rubra, EtOH: Total ethanol extract,

Hx: N-hexane fraction, DCM: Dichloromethane fraction, EtOAc: Ethyl acetate fraction

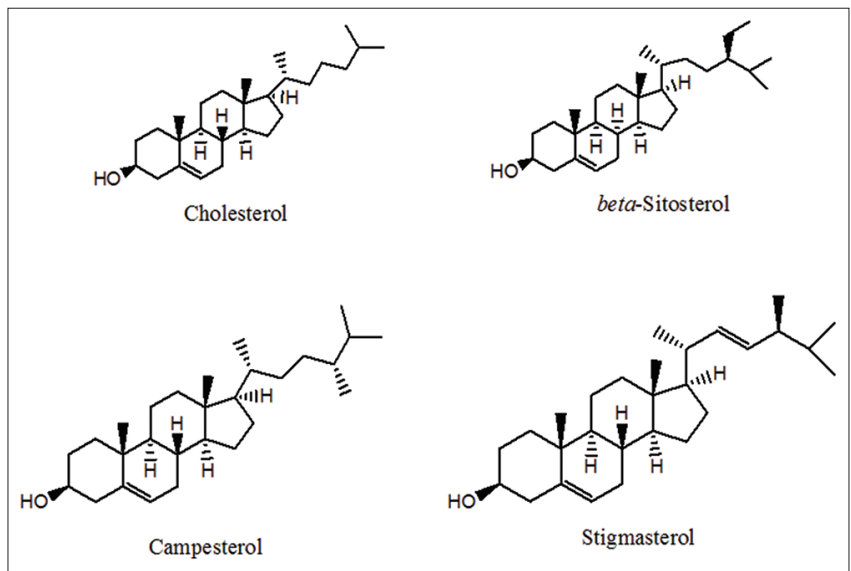

Fig. 1: Sterol compounds identified in Hx fractions of Morus rubra and Morus alba

in $M$. alba, but margaric acid (14.01\%) was the major one in M. rubra saponified fraction. Arachidonic acid was the major unsaturated fatty acids presented in both $M$. alba and M. rubra (10.69\% and $12.69 \%$, respectively) and the lowest one in both fractions was myristoleic acid $(0.85 \%$ and $0.86 \%$, respectively).
GC/MS analysis of total ethanol extracts and successive fractions This study gives a detailed analysis for the first time to the composition of the total EtOH, Hx, DCM and EtOAc of purple M. rubra fruits in comparing with those of white $M$. alba through GC/MS analysis. The structures of the identified compounds I-XXIX in the DCM and EtOAc fractions by GC/MS were illustrated in Figs. 2 and 3. A total of 29 compounds were identified in M. alba and M. rubra fruits.

GC-MS analysis of the DCM fractions of $M$. alba and $M$. rubra showed the presence of 12 and 9 compounds, respectively. Palmitic acid, methyl ester, VI (Fig. 2) was the major compound in both DCM fractions of $M$. alba and M. rubra (66.55\% and 48.51\%) which followed by linolelaidic acid, methyl ester, XI (22.02\%) in M. alba and methyl-9cis,11-trans-octadecadienoate, X (32.00\%) in M. rubra (Table 6 and Fig. 2). The analysis revealed that the identified components of DCM fraction of each of M. alba and M. rubra consist of $99.77 \%$ and $99.87 \%$ oxygenated compounds; whereas, the unoxygenated compounds were $0.23 \%$ and $0.13 \%$, respectively. Esters were the major content in both fractions (96.32\% and 98.81\%, respectively).

GC-MS analysis of the EtOAc fractions of M. alba and M. rubra showed the presence of 12 and 14 compounds, respectively (Table 7). 1,11-bis(Methoxycarbonyl-ethenyl) 10,2-dihydroxycycloeicosane, XXVIII (67.96\%), palmitic acid, methyl ester VI (10.46\%), and 1-benzyloxy2,4-dimethyl-5-hexen-3-ol, XVI (6.25\%) were the major compounds in the EtOAc fraction of M. alba, whereas linolelaidic acid, methyl ester, XI (70.00\%), palmitic acid, methyl ester, VI (12.15\%) and dioctyladipate, XXVII (4.10\%) are the main compounds in the EtOAc fraction of M. rubra (Table 7). The analysis of EtOAc fraction of each of M. alba and M. rubra revealed the presence of oxygenated compounds $99.94 \%$ and $95.66 \%$, respectively. Whereas, the unoxygenated compounds represented $0.06 \%$ and $4.43 \%$, respectively. It was noticed that esters represented $25.58 \%$ and $95.53 \%$, respectively. Pregnane-3,20-diol, XXIX was found only in M. rubra with a total percent $2.08 \%$. The corresponding compounds with their retention times, concentrations (\%) and their nature are shown in Table 7 (Figs. 2 and 3).

GC/MS analysis of total alcoholic EtOH extract of M. alba and M. rubra fruits were carried out, and the structures of the identified compounds 
Table 4: GLC analysis of the unsaponifiable fractions of $M$. alba and $M$. rubra

\begin{tabular}{|c|c|c|c|}
\hline \multirow[t]{2}{*}{ RT } & \multirow[t]{2}{*}{ Compound name } & \multicolumn{2}{|c|}{$\begin{array}{l}\text { Compound } \\
\text { concentration }(\%)\end{array}$} \\
\hline & & M. alba & M. rubra \\
\hline 11.13 & Pentadecane & 0.51 & - \\
\hline 12.25 & Hexadecane & 1.07 & 1.14 \\
\hline 13.63 & Heptadecane & 0.53 & 0.59 \\
\hline 14.85 & Octadecane & 1.91 & 2.98 \\
\hline 16.52 & Nonadecane & 1.11 & 2.51 \\
\hline 16.99 & Eicosane & 2.40 & 2.51 \\
\hline 17.30 & Heneicosane & 2.93 & 2.05 \\
\hline 19.55 & Docosane & 5.01 & 10.58 \\
\hline 20.38 & Tricosane & 2.17 & 7.67 \\
\hline 21.64 & Tetracosane & 5.62 & 5.96 \\
\hline 22.66 & Pentacosane & 1.78 & 7.37 \\
\hline 23.57 & Hexacosane & 8.33 & 7.35 \\
\hline 24.52 & Heptacosane & 13.46 & 1.22 \\
\hline 25.36 & Octacosane & 8.94 & 6.94 \\
\hline 26.24 & Nonacosane & 8.30 & 5.70 \\
\hline 27.04 & Triacontane & 7.86 & 2.39 \\
\hline 28.61 & Cholesterol & 14.54 & 11.96 \\
\hline 29.45 & Campesterol & 5.91 & 6.76 \\
\hline 30.39 & Stigmasterol & 5.17 & 7.09 \\
\hline 31.22 & $\beta$-Sitosterol & 2.45 & 7.23 \\
\hline
\end{tabular}

M. alba: Morus alba, M. rubra: Morus rubra, RT: Retention time in minutes, GLC: Gas liquid chromatography

Table 5: GLC analysis of the fatty acid fractions of $M$. alba and M. rubra

\begin{tabular}{llll}
\hline RT & Compound name & \multicolumn{2}{l}{$\begin{array}{l}\text { Compound } \\
\text { concentration (\%) }\end{array}$} \\
\cline { 3 - 4 } & & M. alba & M. rubra \\
\hline 19.26 & Tridecanoic acid (13:0) & 1.34 & 0.90 \\
21.30 & Myristic acid (14:0) & 1.73 & 1.14 \\
21.94 & Myristoleic acid (14:1) & 0.85 & 0.86 \\
23.77 & Pentadecanoic acid (15:0) & 3.38 & 2.82 \\
29.02 & Palmitic acid (16:0) & 19.54 & 10.56 \\
30.58 & Margaric acid (17:0) & 15.87 & 14.01 \\
31.32 & Palmitoleic acid (16:1) & 4.81 & 6.22 \\
34.24 & Stearic acid (18:0) & 4.28 & 2.54 \\
35.26 & Oleic acid (18:1) & 5.48 & 3.41 \\
36.61 & Linoleic acid (18:2) & 9.77 & 8.06 \\
37.52 & Linolenic acid (18:3) & 6.54 & 12.45 \\
42.53 & Arachidic acid (20:0) & 0.79 & 1.09 \\
43.55 & Arachidonic acid (20:4) & 10.69 & 12.69 \\
45.84 & Behenic acid (22:0) & 1.45 & 3.90 \\
46.66 & cis-13-Docosenoic acid (22:1) & 10.55 & 7.47 \\
48.82 & Tricosanoic acid (23:0) & 2.43 & 9.26 \\
50.49 & Tetracosanoic acid (24:0) & - & 1.62 \\
\hline
\end{tabular}

M. alba: Morus alba, M. rubra: Morus rubra, RT: Retention time in minutes, GLC: Gas liquid chromatography

(XXX-XLVII) were illustrated in Figs. 4 and 5. A total of 18 compounds were identified through GC/MS analysis of EtOH extract of $M$. alba with a total percentage $95.00 \%$ and 10 compounds with $97.11 \%$ in $M$. rubra fruits (Table 8).

The analysis revealed that the identified components of the total ethanol extract of each of the M. alba and M. rubra consist of $89.42 \%$ and $97.00 \%$ oxygenated compounds; in addition, the unoxygenated compounds were $5.58 \%$ and $0.11 \%$, respectively. Hydroxylated compounds, ketones, esters and miscellaneous compounds represented 30.34\%, $3.47 \%, 42.98 \%$ and $18.21 \%$, respectively, in $M$. alba and represented $94.96 \%, 0.04 \%, 1.40 \%$ and $0.71 \%$, respectively, in $M$. rubra. Methyl14-methyl-pentadecanoate, XLIII (Fig. 5) and 1,2-0-isopropylyidene4-nonene-1,2,3-triol, XXXV (Fig. 4) were the major compounds in each extracts (25.86\% and $84.94 \%$, respectively). phenol,4,6-bis (1,1-dimethylethyl)-2-methyl, I (Fig. 2), cyclomulberrin XXXVI (Fig. 4) and nonacosane, XXIII (Fig. 3) were found in EtOH extract of $M$. alba with more ratios $(7.60 \%, 1.59 \%$ and $3.84 \%$, respectively than in $M$. rubra 9.00, 1.02 and 0.11 , respectively).

Palmitic acid methyl ester, VI (Fig. 2) was found only in EtOH extract of $M$. rubra with a ratio $0.66 \%$. Eaters were the major content in total ethanol extract of $m$. alba (30.34\%), whereas the hydroxylated compounds represented the major content in M. rubra (94.96\%).

\section{DISCUSSION}

Various plants have been found to inhibit tumor growth and cause a phenotype reversion in certain cancers. Recently, natural plants have received much attention as sources of biological active substances including antioxidants, antimutagens, and anticarcinogens [18]. The fruits are fast-growing known as Tuta in Sanskrit and Tuti in Marathi and it is also known as Tut in Egypt [19]. Morus comprises 10-16 species of deciduous trees commonly known as mulberries, growing wild and under cultivation in many temperate world regions. Local people in these regions traditionally believe that deep-colored fruits, especially black and purple mulberry fruits, are healthier for the human body [20].

Morus species are well known to contain natural colorant anthocyanins. Anthocyanins, such as cyanidin-3-glucoside and cyanidin-3-rutinoside, were reported that they may have antioxidant capacities and decrease the invasiveness of cancer cells [21]. These compounds exhibited an inhibitory effect on the migration and invasion of a human lung cancer cell line.

The antitumor activity testing was performed as follows: A modified MTT assay was used to examine the antiproliferative activity of the 8 extracts of the two investigated Morus species against 4 human cancer cell lines, PC3, HCT-116, HepG2, and MCF-7.

This study showed antiproliferative and radical scavenging activity of organic solvent fractions (Hx, DCM, and EtOAc) as well as the total ethanol extract EtOH. It was reported that organic extracts may induce higher antiproliferative activity than the water extract in HepG2 cells [19]. This activity may be related to a depression in the levels of AFP, a carcinoembryonic protein and a very important marker of primary HepG2, in HepG2 cells treated with organic solvent extracts. Moreover, the antiproliferative and free radical scavenging potential of M. rubra fruits were established here for the first time.

The data in Table 1 showed five plant extracts with high cytotoxic activity $(\geq 75 \%)$ against at least one cancer cell line. Bioactive phytoconstituents as flavonoids, flavones, flavanones, alkaloids, benzophenones, coumarin derivatives, stilbenes, and terpenoids were present in $M$. alba and M. rubra $[4,20]$ and may be responsible about the antiproliferaive and radical-scavenging activities [8,21,22]. These components are known for their ability to improve human health or decrease the effect of disease $[20,23]$.

The cytotoxic activity assay against almost all cancer cell lines, in this study, showed that the most potent antiproliferative extract was reported for the organic extracts of mulberry (n-hexane from both species as well as the DCM fraction from M. rubra). They showed inhibition of HepG2 hepatoma cells and this activity may be through G2/M phase arrest, induction of apoptosis and inhibition of topoisomerase II $\alpha$ activity [24]. Furthermore, these results were in agreement with the previous work on leukemia cells, declared the plant leaf extract was able to inhibit HL-60 human leukemia cells and B16 mouse melanoma cells [8]. In the current study, the purple mulberry showed higher activity. Deepcolored fruits were reported as a good source of phenolics, including flavonoids, anthocyanins and carotenoids, and mulberries are rich in phenolics [25].

Free radical-scavenging act by preventing the onset of cancer during carcinogenesis, and they are generally beneficial to cells, unlike the 


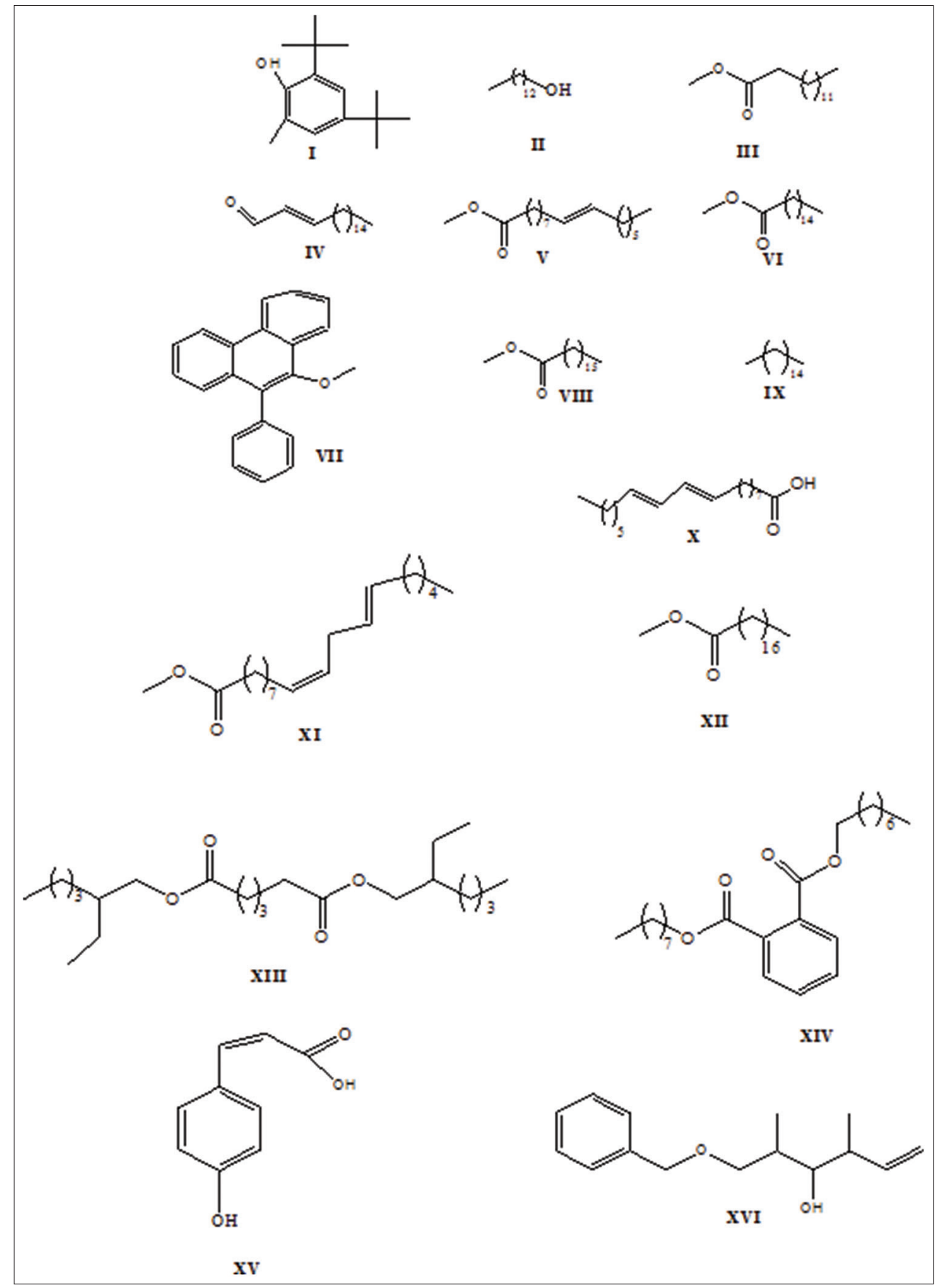

Fig. 2: Structures of the identified compounds (I-XVI) in the dichloromethane and ethyl acetate fractions by gas chromatography/mass spectrometry

cytotoxic agents that damage tumor cells [26]. In recent years, interest has grown in the use of natural antioxidants for the prevention or treatment of cancer and different diseases [27]. A cytotoxic activity included in the cancer chemopreventive agent would be beneficial to eradicate any microscopic cancer lesions that might evolve in early stages. In addition, the cytotoxic extracts were tested on normal human cells to select for extracts safe to normal cells and consequently are expected to be safe on prolonged usage.

Radical-scavenging plays an important role in different stages of cancer development [19]. There is increasing evidence that oxidative processes promote carcinogenesis, although the mechanisms for this are not well understood. Limiting or inhibiting free radical reactions should be able to reduce the rate of cancer incidence.
In the present study, the DCM extract of $M$. alba possessed both free radical scavenging and high potential antiproliferated activities against human cancer cells HCT116 and MCF7 with IC $_{50} 43.9$ and $32.3 \mu \mathrm{g} / \mathrm{ml}$, respectively. While it, fortunately, showed no cytotoxic effect on BJ1. This organic extract of white mulberry fruits may also inhibit the growth of HepG2 cells through suppressing the activity of nuclear factor kappa B gene expression and modulate the biochemical markers [19].

The present results showed that the extraction yields obtained was affected by the solvent used. Difference in yields of extracts affected with the polarity of solvents and various compounds present. The extraction yield was obtained in the following descending order; $\mathrm{EtOH}>\mathrm{EtOAc}>\mathrm{DCM}>\mathrm{Hx}$. Polarity of the solvent, nature of the 


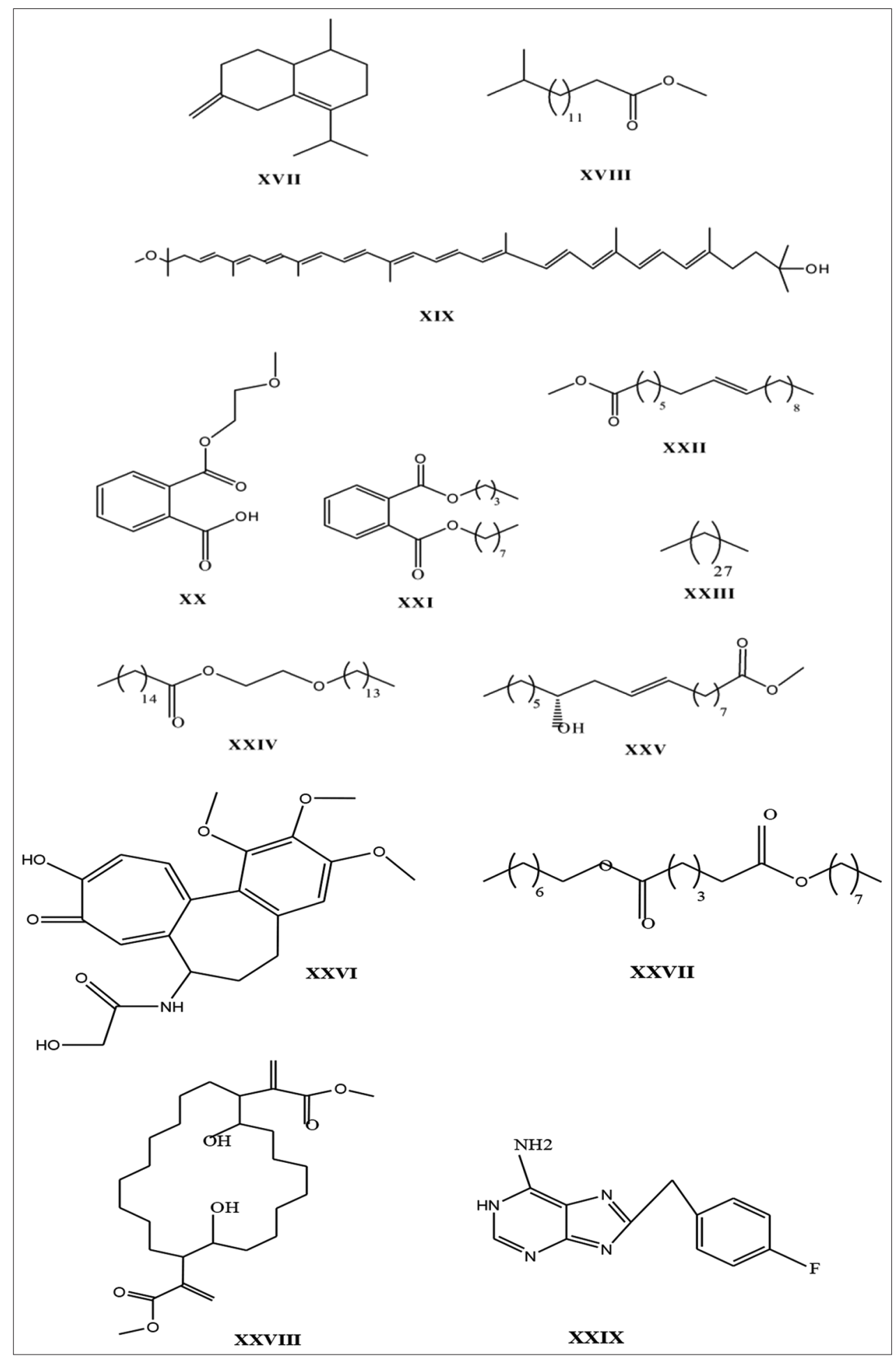

Fig. 3: Structures of the identified compounds (XVII-XXIX) in the dichloromethane and ethyl acetate fractions by gas chromatography/ mass spectrometry

extracted compounds and extraction process highly affects antitumor activity [18].

In the current work, the cytotoxic activity of the Hx fraction of M. rubra against PC3 (51.5\%) and MCF7 (100\%) cancer cells could be slightly attributed to the presence of sterols and unsaturated fatty acids in high content compared with the white mulberry. The sterol content in M. rubra was $33.04 \%$ compared with M. alba (28.07\%), and the unsaturated fatty acids were $51.16 \%$ compared with M. alba (48.69\%). These compounds have been reported to exhibit cytotoxicity against various cancer cells [30].

Palmitic and margaric were found to be the major saturated fatty acids in both current investigated Morus species. Linoleic acid, C18:2, as a representative example $(8.06 \%)$ in $M$. rubra has been reported to possess significant antiproliferative activities [31]. The cytotoxic 
Table 6: GC/MS analysis of DCM fractions of $M$. alba and $M$. rubra

\begin{tabular}{|c|c|c|c|c|}
\hline \multirow[t]{2}{*}{ RT } & \multirow[t]{2}{*}{ Identified compounds } & \multirow[t]{2}{*}{ Number of compound } & \multicolumn{2}{|c|}{ Concentration (\%) } \\
\hline & & & M. alba & M. rubra \\
\hline 31.05 & Phenol, 4,6-di (1,1-dimethylethyl)-2-methyl & I & 0.45 & 0.65 \\
\hline 37.08 & Methyl myristate & III & 1.42 & 3.55 \\
\hline 38.86 & 2-Octadecenal & IV & 0.95 & 0.41 \\
\hline 41.72 & Methyl palmitoleate & $\mathrm{V}$ & 0.75 & - \\
\hline 42.33 & Palmitic acid, methyl ester & VI & 66.55 & 48.51 \\
\hline 43.90 & 10-Methoxy-9-phenyl-phenanthrene & VII & 1.93 & - \\
\hline 43.92 & Ethyl palmitate & VIII & - & 10.76 \\
\hline 44.20 & 2-Hexadecene & IX & 0.23 & 0.13 \\
\hline 46.35 & Methyl-9 cis, 11-trans-octadecadienoate & $\mathrm{X}$ & - & 32.00 \\
\hline 46.40 & Linolelaidic acid, methyl ester & XI & 22.02 & - \\
\hline 47.00 & Methyl stearate & XII & 2.97 & - \\
\hline 52.73 & Adipic acid, bis-(2-ethylhexyl) ester & XIII & 0.31 & 1.58 \\
\hline 55.67 & Dioctyl phthalate & XIV & 2.30 & 2.41 \\
\hline
\end{tabular}

M. alba: Morus alba, M. rubra: Morus rubra, RT: Retention time in minutes, GC/MS: Gas chromatography/mass spectrometry, DCM: Dichloromethane

Table 7: GC/MS analysis of EtOAc fractions of M. alba and M. rubra

\begin{tabular}{|c|c|c|c|c|}
\hline \multirow[t]{2}{*}{ RT } & \multirow[t]{2}{*}{ Identified compounds } & \multirow[t]{2}{*}{ Number of compound } & \multicolumn{2}{|c|}{ Concentration (\%) } \\
\hline & & & M. alba & M. rubra \\
\hline 14.33 & p-coumaric acid & $\mathrm{XV}$ & 0.07 & - \\
\hline 31.04 & 2-Isopropyl-5-methyl-9-methylenebicyclo[4.4.0]dec-1-ene & XVII & 0.06 & 0.21 \\
\hline 37.07 & Methyl myristate & III & - & 0.82 \\
\hline 37.09 & Pentadecanoic acid, 14-methyl, methyl ester & XVIII & 2.26 & - \\
\hline 37.30 & Rhodovibrin & XIX & - & 0.14 \\
\hline 40.85 & Phthalic acid, mono-2-methoxyethyl ester & $\mathrm{XX}$ & - & 0.03 \\
\hline 41.40 & Methyl palmitoleate & $\mathrm{V}$ & - & 0.26 \\
\hline 42.30 & Palmitic acid, methyl ester & VI & 10.46 & 12.15 \\
\hline 43.20 & Phthalic acid, butyloctyl ester & XXI & - & 0.17 \\
\hline 46.31 & Linolelaidic acid, methyl ester & $\mathrm{XI}$ & 5.74 & 70.00 \\
\hline 46.32 & Methyl-9-cis, 11-trans-octadecadienoate & $\mathrm{X}$ & 0.14 & 8.00 \\
\hline 46.46 & 8-octadecenoic, acid methyl ester & XXII & 6.05 & - \\
\hline 50.67 & Nonacosane & XXIII & - & 4.13 \\
\hline 50.83 & Palmitic acid, 2-(tetradecyloxy) ethyl ester & XXIV & 0.88 & - \\
\hline 52.73 & Colchifoleine & XXVI & 0.08 & 1.00 \\
\hline 52.79 & Dioctyl adipate & XXVII & - & 4.10 \\
\hline 55.94 & 1,11-bis-(Methoxycarbonyl-ethenyl)-10,2-dihydroxycycloeicosane & XXVIII & 67.96 & - \\
\hline 56.11 & Pregnane-3,20-diol & XXIX & - & 2.08 \\
\hline
\end{tabular}

M. Alba: Morus Alba, M. Rubra: Morus Rubra, RT: Retention time in minutes, GC/MS: Gas chromatography/mass spectrometry, EtOAc: Ethyl acetate

activity of Morus Hx fraction could be attributed to the presence of palmitic acid (a major component) which has been reported as a potential anticancer drug [32].

On the other hand, the activity of the DCM of white M. alba extract may be attributed to the bioactive phytoconstituents as geranyl-substituted flavanones. These compounds were reported as cytotoxic agents to selected human cancer cell lines and normal human fibroblasts [18]. The anti-metastatic effect of resveratrol, a phenolic compound previously isolated from many Morus species, on the pulmonary metastasis of murine B16 melanoma cells was evaluated [7]. The inhibitory effect of the same compound on the growth of cancer cells and induces apoptosis by acting at multiple cellular targets was reported. In addition, the resveratrol-mediated chemoprevention of rat liver carcinogenesis may be related to alteration of proinflammatory cytokines [33]. Ahmed et al. [6] suggested that the antitumor activity may be due to the presence of phytosterols such as stigmasterol and $\beta$-sitosterol.

The current work reported that margaric acid, palmitic acid, and arachidonic acids were the major fatty acids in purple and white mulberry, whereas cholesterol, stigmasterol, $\beta$-sitosterol and campesterol were the main sterols identified by GLC and the M. alba fruits had the higher total fat content. Palmitic acid was reported as a selective cytotoxic substance [32]. Moreover, the oil containing saturated aliphatic hydrocarbons, as octacosane and triacontane, could induce apoptosis on B16F10-Nex2 melanoma cells and displays antitumor activity [34]. Furthermore, polyunsaturated fatty acids were reported to have cytotoxicity against cancer cells [9]. Fractions containing fatty acids such as linoleic, myristic, and palmitic acids were evaluated for their cytotoxic activity [30]. Consequently, the high cytotoxic activity of Hx successive fraction of purple M. rubra more than $M$. alba reported in this study could be explained on the basis of the presence of a high percentage of unsaturated fatty acids (51.16\%) and phytosterols (33.04\%) found in Hx fraction of $M$. rubra more than those present in $M$. alba (48.69\% for unsaturated fatty acids and $28.07 \%$ for phytosterols).

The GC-MS analysis of DCM and EtOAc extracts, where the corresponding compounds with their retention times, concentrations (\%) and their nature are shown in Tables 6 and 7. The results indicated the presence of compounds of different categories such as phenols, hydrocarbons, esters, alcohols, alkaloids, and other aromatic components in the different extracts.

It was reported that the most of the identified compounds by GC-MS analysis of different successive fractions of M. alba L. were hydrocarbons and fatty acids, where palmitic acid was common compound [35]. 


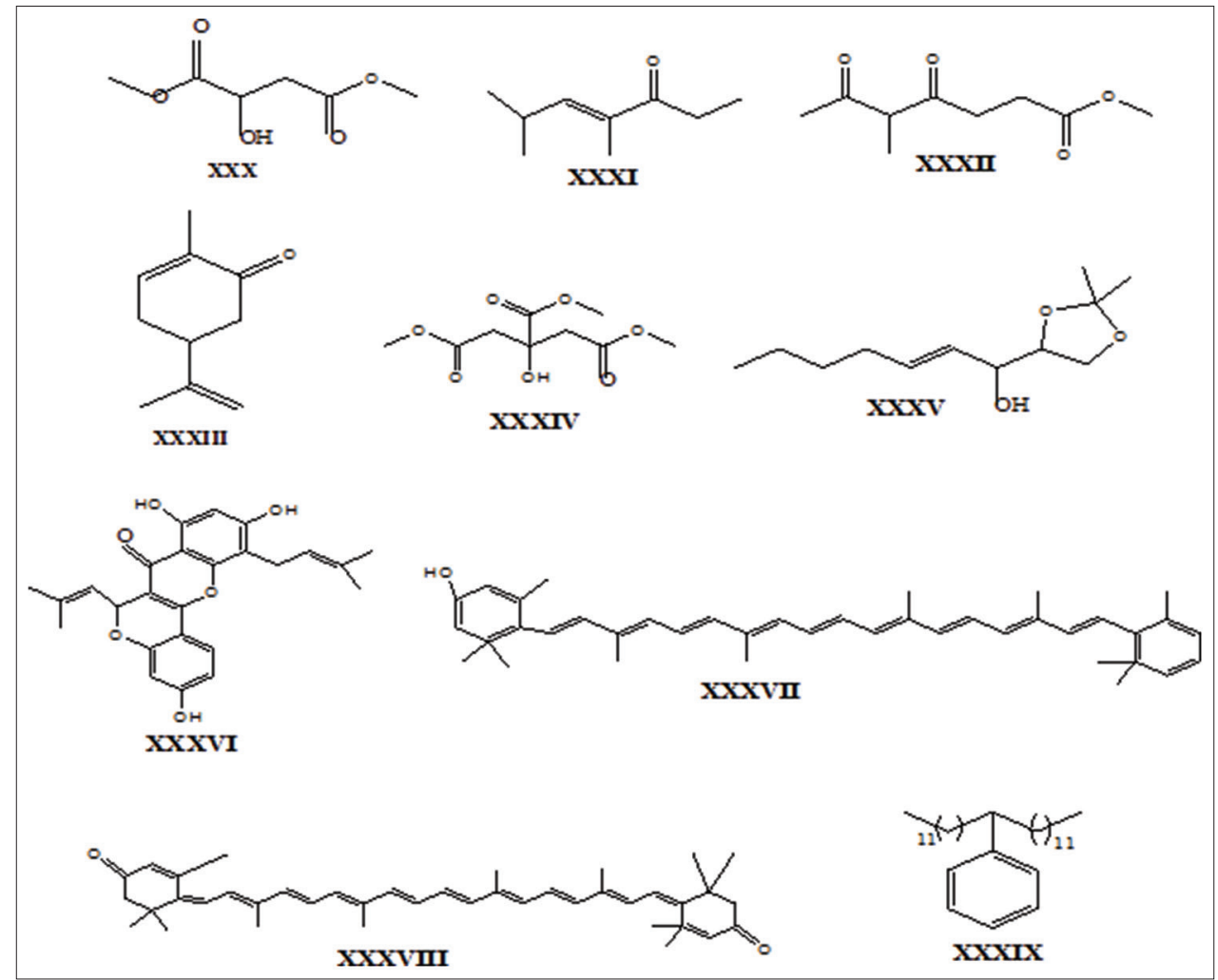

Fig. 4: Structures of the identified compounds (XXX- XXXIX) in the aqueous ethanol extract by gas chromatography/mass spectrometry

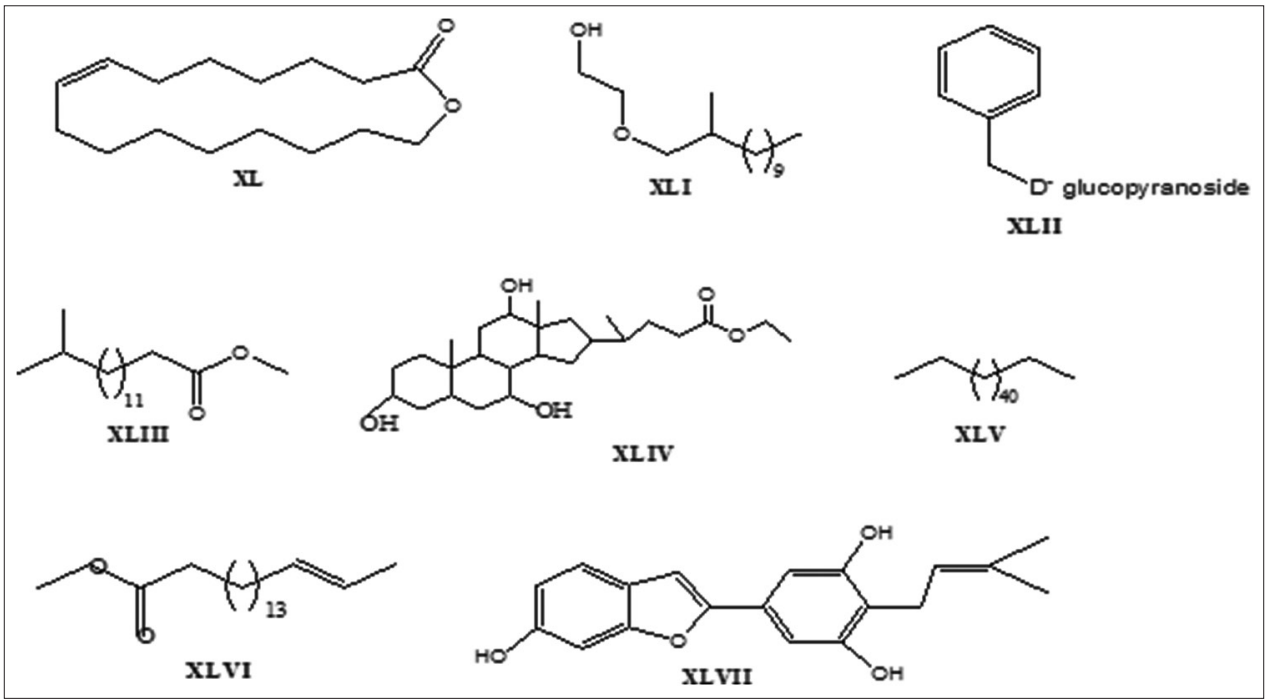

Fig. 5: Structures of the identified compounds (XL-XLVII) in the aqueous ethanol extract by gas chromatography/mass spectrometry

GC/MS analysis of the EtOH extracts of M. alba and M. rubra indicated the presence of compounds of different categories such as esters, ketones, carotenoids, hydrocarbons, and aromatic amines. Alcohol as 1,2-0-isopropylyidene-4-nonene-1,2,3-triol XXXV, phenol as 4,6-bis(1,1-dimethylethyl)-2-methyl I, flavones as cyclomulberrin XXXVI and moracin C XLVII were also identified in these extracts. Cyclomulberrin and moracin $\mathrm{C}$ were previously isolated from the root bark of Morus plants of M. alba [9].

Mulberry fruit contains essential fatty acids that humans cannot synthesize and must be obtained through diet. Essential fatty acids are long-chain polyunsaturated fatty acids derived from linolenic, linoleic, and oleic acids, and they are necessary for the formation of healthy cell membranes, the proper development and functioning of the brain and nervous system [30].

Most of the compounds (Figs. 2-5) detected in Tables 6-8 were related to different categories that have been previously reported to possess anticancer potentials. Phenol-4,6-di-(1,1-dimethylethyl)-2-methyl, I and the phenanthrene derivative, 10-methoxy-9-phenyl-phenanthrene VII were identified in EtOH extract and DCM fraction of M. alba, and they were reported to have antitumor activity and were considered as new pharmacological agents with appropriate biological activity for the treatment of various diseases [36]. The cytotoxic potential effect of many fatty acid methyl esters was reported against three human tumor cell lines [37]. 
Table 8: GC/MS analysis of total ethanol extracts of M. alba and M. rubra

\begin{tabular}{|c|c|c|c|c|}
\hline \multirow[t]{2}{*}{ RT } & \multirow[t]{2}{*}{ Identified compounds } & \multirow[t]{2}{*}{ Number of compound } & \multicolumn{2}{|c|}{ Concentration (\%) } \\
\hline & & & M. alba & M. rubra \\
\hline 19.43 & Malic acid dimethyl ester & $\mathrm{XXX}$ & 6.92 & - \\
\hline 22.34 & Methyl -5-methyl-4,6-dioxoheptanoate & XXXII & - & 0.06 \\
\hline 22.60 & d-Carvone & XXXIII & 2.17 & - \\
\hline 30.06 & Trimethyl citrate & XXXIV & - & 0.59 \\
\hline 30.55 & 1,2-0-Isopropylyidene-4-nonene-1,2,3-triol & XXXV & 6.20 & 84.94 \\
\hline 31.05 & Phenol, 4,6-bis (1,1-dimethylethyl)-2-methyl & $\mathrm{I}$ & 7.60 & 9.00 \\
\hline 32.33 & Cyclomulberrin & XXXVI & 1.59 & 1.02 \\
\hline 34.59 & Anhydrolutein II & XXXVII & 1.36 & - \\
\hline 36.41 & Rhodoxanthin & XXXVIII & 1.00 & - \\
\hline 39.79 & Pentacosane, 13-phenyl & XXXIX & 1.74 & - \\
\hline 40.68 & Oxacycloheptadec-8-en-2-one [Ambrettolid] & $\mathrm{XL}$ & 1.30 & - \\
\hline 41.13 & 1-(2-Hydroxyethoxy)-2-methyl-dodecane & XLI & 3.22 & - \\
\hline 41.89 & Benzyl- $\beta$ - D- glucopyranoside & XLII & 11.45 & - \\
\hline 42.21 & Palmitic acid, methyl ester & VI & - & 0.66 \\
\hline 44.00 & Ethyl iso-allocholate & XLIV & 4.58 & - \\
\hline 46.31 & n-tetratetracontane & XLV & 4.91 & - \\
\hline 46.39 & 16-octadecenoic acid, methyl ester & XLVI & 5.62 & - \\
\hline 46.90 & Methyl stearate & XII & - & 0.09 \\
\hline 55.64 & Colchifoleine & XXVI & 5.36 & 0.60 \\
\hline 55.71 & Moracin C & XLVII & 0.28 & - \\
\hline 58.42 & Nonacosane & XXIII & 3.84 & 0.11 \\
\hline
\end{tabular}

M. alba: Morus alba, M. rubra: Morus rubra, RT: Retention time in minutes, GC/MS: Gas chromatography/mass spectrometry

In several diseases including cancer, the metabolism of essential fatty acids as cis-linoleic and linolenic acid is altered. Thus, these acids and their derivatives have significant clinical implications [30]. The antitumor activity of unsaturated fatty acids may be related to the disturbance provoked on gene expression and protein activity by disrupting cell cycle progression [38]. Unsaturated fatty acids such as oleic (18:1), linolenic acid (18:3), arachidonic (20:4), and cis-13docosenoic (22:1) acids were identified in the $\mathrm{Hx}$ of both mulberry species in the current study. Moreover, the presence of these types of fatty acids could enhance the fluidity of cell membranes in the structures of membrane lipids and resulted in facilitating the entry of anticancer drugs into the cell $[30,38]$. These acids were undergoing lipid peroxidation, yielding free radicals that they react with reactive oxygen species, harming various cell targets.

Colchifoleine, XXVI was related to nitrogenous agents that were reported to have cytotoxic effect in vitro and in vivo experiments [1,5]. Rhodovibrin, XIX (0.14\%) was presented only in EtOAc fraction of M. rubra (Table 7 and Fig. 3). Whereas, anhydrolutein, XXXVII (1.36\%) and rhodoxanthin, XXXVIII $(1.00 \%)$ presented in the EtOH extract of M. alba (Table 8 and Fig. 4), were related to carotenoids. These class of compounds were reported to have anticancer effects in some specific animal models, using specific carcinogens and may be likely responsible for the bioactivities of the Morus plants [5,20,39].

The white mulberry aqueous alcoholic had an effective inhibition effect on the growth of HepG2 cells and may be able to inhibit cell proliferation. The activity may be related to the substantial levels of phenolics, flavonoids, and carotenoids acid present in mulberry species [38]

Decades of research on phytochemistry of genus Morus have led to the identification of various compounds, such as stilbenes, benzofurans, and flavonol glycosides that showed a wide range of bioactive features $[4,9,39]$. In the present study, the radical scavenging activity of ethanolic extract of fruits was concentration-dependent. The fruits of M. rubra in particular exhibit higher antioxidant activity than the white mulberry. M. rubra is one of the most important species of the genus Morus, the fruits containing substantial levels of phenolic compounds [39].

GC-MS and biological assays of organic extracts of the M. rubra fruits established their unique constituents. The deep-colored fruits are a rich source of these compounds, including flavonoids, anthocyanins, and carotenoids $[4,39]$. The radical scavenging activity may be correlated with phenolic constituents of mulberry fruits. Based on the results obtained, Morus fruits were found to serve as a potential source of food diet and natural antioxidants.

\section{CONCLUSION}

The results observed remarkable biological activity of the extracts of M. rubra more than those of M. alba and confirmed its importance as natural bioactive source. Morus species are good candidates to be promising as possible sources for future novel antitumor and antioxidants in food and pharmaceutical formulations. The strong activity partly explains the potential effects of Morus species for the treatment of cancer and degenerative diseases caused by free radicals. Due to their active contents, it seems that these plants are worth investigating for further studies to evaluate the antioxidant, anticancer efficacy and general toxicity of the active extracts, especially the promising of DCM fraction of M. alba, in animal models. However, further merit investigations including clinical study are necessary in the future to confirm this hypothesis.

\section{REFERENCES}

1. Cragg GM, Newman DJ. Natural products: A continuing source of novel drug leads. Biochim Biophys Acta 2013;1830(6):3670-95

2. Lobo V, Patil A, Phatak A, Chandra N. Free radicals, antioxidants and functional foods: Impact on human health. Pharmacogn Rev 2010;4(8):118-26.

3. Awad HM, Abd-Alla HI, Mahmoud KH, El-Toumy SA. In vitro antinitrosative, antioxidant, and cytotoxicity activities of plant flavonoids: A comparative study. Med Chem Res 2014;23(7):3298-307.

4. Kähkönen MP, Heinämäki J, Ollilainen V, Heinonen M. Berry anthocyanins: Isolation, identification and antioxidant activities. J Sci Food Agric 2003;83(14):1403-11.

5. Burlando B, Clericuzio M, Cornara L. Moraceae plants with tyrosinase Inhibitory activity: A review. Mini Rev Med Chem 2017;17(2):108-21.

6. Ahmed HH, Hegazi MM, Abd-Alla HI, Eskander EF, Ellithey MS. Antitumour and antioxidant activity of some Red Sea seaweeds in ehrlich ascites carcinoma in vivo. Z Naturforsch C 2011;66(7-8):367-76.

7. Bishayee A, Politis T, Darvesh AS. Resveratrol in the chemoprevention and treatment of hepatocellular carcinoma. Cancer Treat Rev 2010;36(1):43-53 
8. Takuya K, Yukikazu Y. Apoptosis-inducing activity of ethanol extracts from the tea of mulberry (Morus alba) leaves in HL-60 cells. J Jpn Soc Food Sci Technol 2009;49(4):195-8.

9. Wei H, Zhu J, Liu XQ, Feng WH, Wang ZM, Yan LH. Review of bioactive compounds from root barks of Morus plants (SangBai-Pi) and their pharmacological effects. Cogent Chem 2016;2. DOI: 10.1080/23312009.2016.1212320.

10. Aly HF, Abd-Alla HI, Ali SA, Mamdooh M, Alez RA, Abu-Krisha MT. Statistical data analysis which result from the bio-diagnosis and biotreatment of injured rats with the hyperlipidemia and hyperglycemia diseases. Asian J Pharm Clin Res 2016;9(3):122-30.

11. Abd-Alla HI, Elnenaey HM, Hassan AZ, Taie HA, Abo-Shnaf RI, Hussein AM. Bioactive metabolites from two local cultivars of Ricinus communis and their free radical scavenging and acaricidal activities. Der Pharm Chem 2015;7(4):5-18.

12. Mosmann T. Rapid colorimetric assay for cellular growth and survival: Application to proliferation and cytotoxicity assays. J Immunol Methods 1983;65(1-2):55-63.

13. Thabrew MI, Hughes RD, McFarlane IG. Screening of hepatoprotective plant components using a HepG2 cell cytotoxicity assay. J Pharm Pharmacol 1997;49(11):1132-5.

14. Goveas S, Abraham A. Evaluation of antimicrobial and antioxidant activity of stem and leaf extracts of Coscinium fenestratum. Asian J Pharm Clin Res 2013;6(3):218-21.

15. Johnson AR, Davenport JB. Biochemistry and Methodology of Lipids. New York: John Wiley and Sons, Inc.; 1971. p. 31.

16. Vogel AI. Textbook of Practical Organic Chemistry. $3^{\text {rd }}$ ed. London: Longman's Green and Co., Ltd.; 1966. p. 133-6.

17. Adams RP. Identification of Essential Oils by Ion Trap Mass Spectroscopy. New York: Academic Press Inc.; 1995.

18. Jyoti A, Anand K, Sunanda P. Synergistic action of phytochemicals augments their antioxidative efficacy: An in vitro comparative study. Asian J Pharm Clin Res 2013;6(4):121-6.

19. Fathy SA, Singab AB, Nagwa SA, Abd El-Hamid DM, Zahra FA, Abd El-Moneim SM. The antiproliferative effect of mulberry (Morus alba L.) plant on hepatocarcinoma cell line HepG2. Egypt J Med Hum Genet 2013;14(4):375-82.

20. Ercisli S, Tosun M, Duralija B, Voca S, Sengul M, Turan M. Phytochemical content of some black (Mors nigra L.) and purple (Morus rubra L.) mulberry genotypes. Food Technol Biotechnol 2010;48(1):102-6.

21. Chen PN, Chu SC, Chiou HL, Kuo WH, Chiang CL, Hsieh YS. Mulberry anthocyanins, cyanidin 3-rutinoside and cyanidin 3-glucoside, exhibited an inhibitory effect on the migration and invasion of a human lung cancer cell line. Cancer Lett 2006;235(2):248-59.

22. El-Baz FK, Khalil WK, Aly HF, Booles HF. Berry extracts improved inflammatory cytokines, antioxidant enzyme and suppressed the gene expression alterations in diabetic rats. Int J Pharm Pharm Sci 2016;8:1-9.

23. Taie HA, Abd-Alla HI, Ali SA, Aly HF. Chemical composition and biological activities of two Solanum tuberosum cultivars grown in Egypt. Int J Pharm Pharm Sci 2015;7(6):311-20.

24. Naowaratwattana W, De-Eknamkul W, De Mejia EG. Phenoliccontaining organic extracts of mulberry (Morus alba L.) leaves inhibit HepG2 hepatoma cells through G2/M phase arrest, induction of apoptosis, and inhibition of topoisomerase IIa activity. J Med Food 2010;13(5):1045-56.

25. Lin JY, Tang CY. Determination of total phenolics and flavonoid contents in selected fruits and vegetables, as well as their stimulatory effects on mouse splenocyte proliferation. Food Chem 2007;101(1):140-7.

26. Valko M, Leibfritz D, Moncol J, Cronin MT, Mazur M, Telser J. Free radicals and antioxidants in normal physiological functions and human disease. Int J Biochem Cell Biol 2007;39(1):44-84.

27. Gago-Dominguez M, Jiang X, Castelao JE. Lipid peroxidation, oxidative stress genes and dietary factors in breast cancer protection: A hypothesis. Breast Cancer Res 2007;9(1):201.

28. Hecht F, Pessoa CF, Gentile LB, Rosenthal D, Carvalho DP, Fortunato RS, et al. The role of oxidative stress on breast cancer development and therapy. Tumour Biol 2016;37(4):4281-91.

29. Hwang YJ, Lee EJ, Kim HR, Hwang KA. In vitro antioxidant and anticancer effects of solvent fractions from Prunella vulgaris var. Lilacina. BMC Complement Altern Med 2013;13:310.

30. Menéndez JA, del Mar Barbacid M, Montero S, Sevilla E, Escrich E, Solanas M, et al. Effects of gamma-linolenic acid and oleic acid on paclitaxel cytotoxicity in human breast cancer cells. Eur J Cancer 2001;37(3):402-13.

31. Achenef B, Arifah K. Cytotoxic effects of conjugated linoleic acids on human breast cancer cells (MCF7). Acad J Cancer Res 2012;5(1):11-6.

32. Harada H, Yamashita U, Kurihara H, Fukushi E, Kawabata J, Kamei Y. Antitumor activity of palmitic acid found as a selective cytotoxic substance in a marine red alga. Anticancer Res 2002;22(5):2587-90.

33. Mbimba T, Awale P, Bhatia D, Geldenhuys WJ, Darvesh AS, Carroll RT, et al. Alteration of hepatic proinflammatory cytokines is involved in the resveratrol-mediated chemoprevention of chemically-induced hepatocarcinogenesis. Curr Pharm Biotechnol 2012;13(1):229-34

34. Figueiredo CR, Matsuo AL, Pereira FV, Rabaça AN, Farias CF, Girola N, et al. Pyrostegia venusta heptane extract containing saturated aliphatic hydrocarbons induces apoptosis on B16F10-Nex2 melanoma cells and displays antitumor activity in vivo. Pharmacogn Mag 2014;10 Suppl 2:S363-76

35. Yashvanth S, Rani SS, Madhavendra SS. Morus alba L. A new perspective: Scanning electron microscopic, micro chemical, GC-MS and UPLC-MS Characterisation. Int J Res Pharm Chem 2015;5(1):106-15

36. de Azeredo SO, Figueroa-Villar JD. Phenanthrene derivatives for synthesis and applications in medicinal chemistry: A review. World J Pharm Pharm Sci 2014;3:1362-79.

37. Lima LA, Alves TM, Zani CL, Pimenta LP, Boaventura MA. Antioxidant and cytotoxic potential of fatty acid methyl esters from the seeds of Annona cornifolia A. St.-Hil. (Annonaceae). Food Res Int 2012;48(2):873-5.

38. Sayegh F, Elazzazy A, Bellou S, Moustogianni A, Elkady AI, Baeshen MN, et al. Production of polyunsaturated single cell oils possessing antimicrobial and anticancer properties. Ann Microb 2016;66(3):937-48.

39. Dimitrijević DS, Kostić DA, Stojanović GS, Mitić SS, Mitić MN, Đorđević AS, et al. A survey on macro - And micro-elements, phenolic compounds, biological activity and use of Morus spp. (Moraceae). Fruits 2013;68:333-47. 